\section{Apropriação, desvio e despesa na cibercultura ${ }^{1}$}

\section{RESUMO}

Este artigo trata do imaginário cyberpunk, que condiciona a cibercultura, fazendo o resgate das origens e das associações do termo e da sua relação com os cyberpunks e com 0 underground da informática.

\section{ABSTRACT}

This article discusses the role of the imaginary of the cyberpunk culture, reevaluating the origin and the associations of the concept as well as its relationship with the cyberpunks and the underground of the digital community.

\section{PALAVRAS-CHAVE}

- Imaginário (Imaginary)

- Cibercultura (Cyberculture)

- Novas tecnologias (New technologies)

\section{André Lemos ${ }^{2}$}

Prof. Fac. Comunicação Univ. Fed. Bahia (FACOM/UFBA)
O IMAGINÁRIO CYBERPUNK marca toda a cibercultura. O termo tem suas origens no movimento homônimo de ficçãocientífica que associa tecnologias digitais, psicodelismo, tecnomarginais, ciberespaço, cyborgs e poderes midiático, político e econômico dos grandes conglomerados multinacionais.

Além da ficção, todo o imaginário da cibercultura vai ser alimentado pela ação dos cyberpunks reais, o underground da informática com os phreakers, hackers, crackers, ravers, zippies, cypherpunks e otakus. ${ }^{3}$ Vejamos algumas definições do conceito:

"Uma emergente subcultura jovem, fusionando antiautoritarismo punk com amor pelas tecnologias de ponta". "Os soldados pioneiros do século $X X I$. Embarcando na nova fronteira eletrônica."4

"Um modo de vida centrado nas tecnologias computacionais, música hardcore e agressividade adolescente. O cyberpunk nos dá a habilidade de ser livre. A tecnologia pertence ao jovem e deve ser explorada em seu proveito. Esta é a nova era...." ${ }^{5}$

A ficção científica cyberpunk aparece como um reflexo do que já acontecia no quotidiano. Por isso, seus expoentes dizem não falar do futuro, mas fazer uma paródia do presente. No entanto, fora da ficção-científica, o imaginário cyberpunk aparece em vários formatos da cultura contemporânea ${ }^{6}$, sendo o hacking a ação comum a todos eles. Para R. U. Sirius, editor da revista californiana Mondo 2000, o hacking (como veremos, ação emblemática da cibercultura) é uma forma de "controlar nosso destino". ${ }^{7}$ Podemos 
colocar nessa perspectiva a atuação de artistas eletrônicos, os ativistas da fronteira eletrônica, os hackers e crackers. O underground high-tech é uma atitude contra a tecnocracia que criou a informática. Para Sirius, ele é a expressão ${ }^{8}$

"de uma nova formação social configurada eletronicamente chamada cibercultura (...) e que nos convida a cruzar o espaço de dados, cavalgar a onda eletrônica, hip hop os seus laptops, passear na realidade virtual, projetar comidas e plugar em sincroenergéticos e drogas inteligentes garantindo ampliar nossa potência cerebral e nossa vida sexual". ${ }^{9}$

O cyberpunk tenta nos convencer de que estamos frente a uma revolução cultural sem precedentes que une, de modo inédito, a jovem cultura urbana e as tecnologias digitais: a cultura do caos e as novas tecnologias (Ruskoff). ${ }^{10} \mathrm{~A}$ cibercultura, da qual o cyberpunk é um dos timoneiros, é o resultado de uma revolução sem slogans, sem ideologias e sem emblemas históricos; uma rebelião intersticial na fronteira eletrônica, a New Edge.

A cibercultura permite, assim, a fusão entre a New Edge high-tech e a New Age naturalista, espiritualista e hedonista. $\mathrm{O}$ cyberpunk é filho direto da contracultura.

A contracultura dos anos 60 , que fundia liberalismo e tecnologia (rock, vídeo e cinema experimentais...) rejeita, no plano global, o alargamento dos impactos da tecnologia na vida quotidiana. Embora a cultura cyberpunk possa ser vista como herdeira da contracultura, ela não é mais antitecnológica, nostálgica. Na realidade, a celebração das novas possibilidades abertas pelas tecnologias eletrônicas pode ser vista como uma alienação levada ao nível de êxtase. ${ }^{11}$

imaginário cyberpunk impõe, assim, uma visão ao mesmo tempo cínica e distópica em relação às possibilidades abertas pelas novas tecnologias. Aqui, o futuro não faz mais sentido e as grandes metanarrativas desabaram. O lema dos cyberpunks é: a informação deve ser livre; o acesso aos computadores deve ser ilimitado e total. Desconfie das autoridades, lute contra o poder; coloque barulho no sistema, surfe essa fronteira, faça você mesmo.

A primeira expressão da cultura cyberpunk surge na ficção-científica, caracterizando-se por uma visão pessimista ou distópica do futuro. Dentro de uma visão conspiratória, que deve muito à literatura americana do pós-guerra, a sociedade é dominada por grandes corporações que controlam a política e a economia mundial. As redes de computadores são o centro nervoso da vida social neste futuro paródia do presente.

O prefixo ciber vem de cibernética, a ciência do estudo do controle de processos de comunicação entre homens e máquinas, homens e homens, e máquinas e máquinas.

O punk revela a atitude, a força da rua no que nela há de mais trágico, imediato e violento. Os cyberpunks são outsiders, criminosos, visionários da tecnologia. Eles encarnam, na ficção e na vida real, uma atitude de apropriação vitalista da tecnologia.

O universo de sua ficção está, justamente, na conjunção social do reino da tecnologia de ponta, da racionalidade, da hard-science, com o lado subterrâneo, hedonista e tribal da sociedade de hoje. Como parte da cibercultura, o estilo cyberpunk aponta para uma sinergia entre as tecnologias digitais do ciberespaço e a socialidade contemporânea.

Sendo assim, se não há mais utopia possível, isto não implica, entretanto, uma homogeneização e um controle total da vida social. Se a modernidade criou o imaginário da técnica infalível e positiva, apontando para o futuro, a cibercultura está ancorada no presente. A maçã mordida do Macintosh é o símbolo do fracasso do homem individualista, emancipado, racional e objetivo. Em lugar de ser o momento do 
desencanto radical do mundo esboçado por Orwell, o verdadeiro ano de 1984 parece ser uma espécie de reencantamento da tecnologia contemporânea. Neuromancer de William Gibson ${ }^{12}$ é, assim, o trabalho que melhor reflete a cultura tecnourbana dos anos 80 . O livro populariza o movimento cyberpunk na ficção-científica. $\mathrm{E}$, o mais importante, ele vai formar e ampliar o imaginário da cibercultura. Não vou me alongar muito, pois essa temática foi desenvolvida em um outro trabalho. O objetivo aqui é relacionar o cyberpunk às noções de apropriação, despesa improdutiva e desvios de comportamento.

\section{A rua e a tecnologia}

Os cyberpunks reais

A formação do underground high-tech é diretamente influenciada pela contracultura americana e pela consolidação da sociedade dos meios de comunicação de massa.

O desenvolvimento das tecnologias de comunicação microeletrônicas, assim como a atitude sociocultural dos anos 60-70, contribuem para a emergência de dois fenômenos muito importantes para a consolidação da cultura cyberpunk: os phreakers e os hackers, os primeiros e verdadeiros cyberpunks da rua. R. U .Sirius explica:

"As primeiras pessoas a se identificarem como cyberpunks foram hackers adolescentes relacionados aos personagens dos mundos criados nos livros de William Gibson, Bruce Sterling, John Shirley, e outros". ${ }^{13}$

Os últimos ataques contra os gigantes do e-business, no começo de 2000, e o crescimento exponencial de ataque de hackers brasileiros, já em 2001, com os recentes ataques a Nasdaq, Dell, Ministério da Defesa e Nike, são exemplares. Importa aqui a compreensão de que os verdadeiros hackers, ao contrário dos marginais ou vândalos, buscam desmascarar a falta de segurança de sistemas e revelar o papel das novas tecnologias de informação na sociedade globalizada.

A idéia básica é não recusar, mas dispor da tecnologia para combater, em pequenas guerrilhas, as derrapagens do sistema global.

A atitude cyberpunk é, assim, negativa em dois níveis: o pessimismo (em relação ao futuro, às ideologias) e o descontentamento para com a tecno-estrutura. Ela não é, contudo, antitecnológica. O tecno-anarquismo (grupos como Legion of Doom, Hacktic, CCC, Loft, entre outros) é uma forma de negação do poder da tecnocracia e uma maneira de afirmar, de forma positiva, a vitalidade social através das novas tecnologias.

O intenso e imediato prazer em tempo real, o desprezo pelo futuro, a aventura e a conquista de novos territórios simbólicos, a anarquia do ciberespaço, as agregações sociais, todas características da cibercultura, mostram o vitalismo social contemporâneo no coração da tecnologia digital. Vejamos algumas definições sobre cyberpunks no newsgroup alt.cyberpunk:

Tue, 21 Dec 1993 18:39:20 GMT alt.cyberpunk $>$ You cannot be a cyberpunk and at the same time agree that $>$ certain information should be banned, censored or outlawed.

Date: Mon, 10 Jan 1994 05:44:16 GMT

$>$ I totally disagree. I think cyberpunks truly enjoy the idea of living $>$ in a 'Blade-runnerish' future, but they know that in reality, its not >going to largely happen. However, in Blade-runner \& the like, we really >never got to see what the rest of the world was like. The cyberpunkers of course will >choose to live in the 
cities, (LA, Tokyo, NY etc.)

Your cpunk may live in a fictional world, mine doesnt, and Im sure that many out there will say that there life is not fictional. It is more like the ideas of the hackers of California and Berkley. To bring tech to the people, and put the power in the hands of the masses thru technology.

Tue, 21 Dec 1993 18:45:11 GMT

alt.cyberpunk

Flux 1 parmi 10

Article 794 Re: A Call to Arms

shroom@theporch.raider.net

sHrOom at The Maclnteresteds of Nashville, Tn.

$>$ Well what's your definition? Come on, put it out on the street. Or isn't

$>$ that information free?

My belief is that information should be free

If you have to break the law to learn, then do it.

Os cyberpunks reais não são homogêneos. O núcleo comum das tribos eletrônicas é a mistura de fascinação, de apropriação, de diversão e de impertinência em relação às tecnologias do ciberespaço.

Segundo afirmam os próprios cyberpunks, eles procuram o prazer, o conhecimento e a comunicação através do uso intensivo das tecnologias do ciberespaço e de uma crítica feroz ao desenvolvimento tecnológico. O discurso parece ser: queremos o ciberespaço, mas não o Rwindow\$; queremos Internet, mas não vigilância eletrônica e spams; queremos informação livre, mas não sites inseguros que possam ferir a nossa privacidade, etc...

Podemos ver o fenômeno como um processo social onde a socialidade ${ }^{14}$ se dá através da apropriação destas novas tecnologias. $E$ isto para o melhor (a efervescência comunal, o compartilhar de sentimentos, a informação altruísta, etc.) ou para o pior (criminalidade, ausência de contato físico, terrorismo, vírus, pedofilia, etc.).

A geração dos anos 80 irá popularizar - conceito através dos media de massa (jornais, revistas, TV), definindo-os como os piratas das redes de computadores.

A percepção social será elaborada de tal forma, que os hackers não serão mais vistos como exploradores do ciberespaço, mas como intrusos maliciosos e perversos. ${ }^{15}$

O filme War Games (1983) ajuda na formação desta cultura dos hackers dos anos 80. Pela primeira vez, o grande público via o phone phreaking, o hacking, a social engineering e outras práticas que já estavam nas ruas. Antes, em 1982, o filme Blade Runner dá a estética do movimento. Vejamos alguns depoimentos de hackers conhecidos:

Michael Synergie (hacker): "Eu sou um dependente, um junkie sensório. Eu quero incentivos, e imediatamente. Quando eu penetro os sistemas de computador eu não olho nada: correio pessoal, artigos, notas, programas, etc. Eu preciso aprender. Eu sou um pesquisador de cabeça e eu preciso saber tudo que posso".

The Mentor (membro do Legion of Doom): "Esse é o nosso mundo. O mundo de elétrons, beleza e baud. Usamos os servidores existentes sem pagar e eles nos identificam como criminosos. Nós exploramos... e você diz que nós somos os criminosos. Nós existimos sem distinguir a cor da pele, a nacionalidade, a religião... e você diz que nós somos os criminosos. Você constrói algumas bombas atômicas, você faz a guerra, você mata, você mente e você tenta nos convencer que é para nossa felicidade; novamente, nós é que somos os criminosos. Meu crime é a curiosidade. Meu crime é julgar as pessoas pelo o que elas dizem ou pensam (...). Eu sou um hacker e esse é meu manifesto. Você 
pode parar um de nós, mas você não nos pode parar tudo".

Emmanuel Goldstein (Editor da Revista 2600): "Os hackers são aqueles que fazem muitas perguntas e aqueles que não acreditam na obediência às regras todo o tempo. Se alguém dissesse: nunca faça isso, eles não aceitam e vão fazer o que é proibido fazer".

Rop Gonggrijp (membro do Grupo tecno-anarquista holandês HACTIC): "o verdadeiro papel dos hackers é político, quer dizer, são as pessoas que fazem progredir a informática. Os hackers estão lutando para conectar qualquer pessoa fora da tecnocracia. Eles são os atores da passagem da tecnocultura à cibercultura".

O espírito da cibercultura: entre apropriação, desvio e despesa improdutiva

O hacking é o símbolo maior da cibercultura, podendo ser visto pela ótica da astúcia dos usos (Perriault), do desvio (Becker) e da despesa improdutiva (Bataille). Neste sentido, as novas tecnologias da cibercultura estão em relação estreita com a dinâmica social contemporânea. Vamos mostrar que esta dinâmica estabelece-se quando a microinformática é apropriada pela vida social, alimentando as indústrias do virtual.

Esta apropriação se dá como um método de improvisação, onde os desvios do uso são responsáveis pelos desenvolvimentos na indústria da informática e por sua popularização. Assim, a sociedade da informação entra numa fase de excesso e de profusão desenfreada de informações.

A forma como os media tradicionais tratam o fenômeno do hacking reforça a infantilização desta cultura, como um modo de torná-la trivial e com isso neutralizá-la.
Como vimos, o hacker pode ser visto como um ativista que mistura negligência e interesse, marcado por uma nova relação entre a contracultura e as tecnologias microeletrônicas. Se a contracultura dos anos 70 foi baseada, como mostra Ross, numa tecnologia do folclore (orientalismo, misticismo, idéias antitecnológicas, natureza), a cibercultura seria uma cultura baseada numa espécie de folclore da tecnologia (realidade virtual, ciberespaço, pós-humanismo). Para Ross, a cultura contemporânea deve ser capaz

"de reescrever os programas culturais e reprogramar os valores sociais que fazem o terreno das novas tecnologias; um conhecimento hacker, capaz de gerar novas narrativas populares ao redor de usos alternativos da ingenuidade humana". ${ }^{16}$

É a partir da idéia do hacking que se forma o imaginário da cibercultura. Notamos a popularização e até mesmo a trivialização deste imaginário onde a máxima é: tudo pode na Internet, a Rede é livre, a informação deve ser livre, a privacidade é um direito inalienável, etc. O acesso às redes de computadores, à realidade virtual, aos jogos eletrônicos, às imagens de síntese, às manipulações digitais na música eletrônica, vão exprimir este espírito transgressor e desviante como forma de apropriação, chegando a sua disseminação pelo corpo social, atingindo, mesmo indiretamente, todas as pessoas que têm acesso às novas tecnologias.

A cibercultura é a popularização da atitude dos cyberpunks, tendo no hacking seu emblema fundamental. Este é a expressão de uma astúcia do quotidiano, permitindo a apropriação social da tecnologia em um contexto de desvios e excessos.

Apropriação 
Podemos dizer que a cibercultura nasce pela apropriação tecnológica. Como afirma Castells, a cibercultura, ou a sociedade informacional, é fruto da sinergia da Big Science, dos militares e do underground. ${ }^{17}$ A cibercultura é, diferentemente da atmosfera eletromecânica do começo do século $X X$, favorável a novas formas de apropriação social dos objetos tecnológicos. O quotidiano é o terreno onde se desenvolve uma maneira, senão inteiramente nova, ao menos inusitada, de relação entre os homens e a tecnologia: a atitude cyberpunk (raiz da cibercultura) é expressão desta batalha contraditória entre os homens e seus artefatos.

Estamos no coração da sociedade pós-industrial, associando assepsia científica e tecnológica ao caos urbano e ao lado dionisíaco da socialidade contemporânea. Assim sendo, o imaginário tecnológico da cibercultura parece estar em ruptura com os paradigmas que legitimaram o imaginário da modernidade. Para os principais expoentes da cibercultura, como vimos, o hacking mostra a apropriação quotidiana da técnica no presente, sem engajamento perene ou idéia de utopia tecnológica.

As novas possibilidades oferecidas pela revolução da informática permitem que a rua possa influenciar os destinos da tecnologia. Podemos dizer que há um processo de diferenciação social produzido por micropoderes, por ações de grupos ativistas (hackers, cypherpunks, zippies, ravers, etc.) que vão compor o mosaico de forças entre a tecnologia e a vida social. Ao desencantamento do mundo (Max Weber), os cyberpunks propõem a seguinte solução: "sobreviver graças a truques (hacks), piratarias, tráfico de signos, de linguagens, de conexões". ${ }^{18}$ A análise da lógica dos usos, desenvolvida por Jacques Perriault, será útil aqui para entendermos a cibercultura e, mais especificamente, a real participação dos cyberpunks.

De acordo com Perriault, o uso dos objetos tecnológicos não é apenas tributário das estratégias de empreendimentos de acordo com a objetividade da função do objeto, ou de acordo com uma racionalidade técnica intrínseca aos modos de usar (manuais técnicos). Sua hipótese é de que "os usuários têm uma estratégia de utilização dessas máquinas de comunicação". ${ }^{19}$ A sociologia dos usos visa, assim, a entender o modo pelo qual usamos os objetos técnicos no quotidiano, descrevendo uma perspectiva que flutua entre a etnometodologia e a psicologia. Talvez seja mais apropriado falar em astúcia dos usos, já que este termo, mais aberto ao imprevisto, escapa à idéia de lógica, como sustenta Perriault. Sabemos, com De Certeau ${ }^{20}$, como os usuários inventam o quotidiano, como eles investem conteúdos simbólicos, imprimindo seus traços na mais banal ação do dia-a-dia. Não há uma lógica, mas antes uma dialógica complexa (Morin) entre os objetos, os usos e as obrigações funcionais destes mesmos objetos.

A apropriação tem sempre uma dimensão técnica (o treinamento técnico, a destreza na utilização do objeto) e uma outra simbólica (uma descarga subjetiva, o imaginário). A apropriação é, assim, ao mesmo tempo forma de utilização, aprendizagem e domínio técnico, mas também forma de desvio (deviance) em relação às instruções de uso, um espaço completado pelo usuário na lacuna não programada pelo produtor/inventor, ou mesmo pelas finalidades previstas inicialmente pelas instituições.

Pela apropriação está em jogo um certo esvaziamento do totalitarismo do objeto. Como mostra Schwach ${ }^{21}$, a sociologia do uso tem por objetivo descortinar o usuário sob o ponto de vista psicológico e sociológico, com o mérito de ter retirado desses estudos os preconceitos antitecnológicos.

Sabemos que o uso de um objeto tecnológico, do mais simples aos mais complexos, nunca está dado, sendo, também, determinado 
por suas utilizações. Os sociólogos do uso trabalham com ideais tipo weberianos, estando mais interessados em descrições ancoradas, em geral, sobre a vida social e psíquica de cada usuário. As categorias socioeconômicas rígidas identificam os usos de acordo com velhos diagramas que não consideram nem a subjetividade, nem as influências psicológicas, nem as mudanças culturais mais sutis. De acordo com Schwach, é necessário deixar as portas abertas a uma transdisciplinaridade em três níveis: a funcionalidade técnica, os mecanismos psicológicos de apropriação e o fazer coletivo, sociológico.

Segundo Perriault, haveria uma linhagem que uniria as máquinas de comunicação aos seus respectivos usos. Esta linhagem é marcada, em toda a história dos media, por um desejo de simulação. A cibercultura estaria, dessa forma, marcada pelas tecnologias da simulação, proporcionando o sentimento de descolamento do aqui e agora, do espaço e do tempo. As tecnologias do virtual seriam, então, um resultado desse desejo onde "o uso das máquinas de comunicação favorece a criação de redes de sociabilidade (...)". ${ }^{22}$ Sendo assim, ao analisar os usuários devemos superar a perspectiva do uso correto ou não das máquinas de comunicação, marcados para sempre pelo estigma do consumidor passivo e envolvido por uma rede de estratégias dos produtores. Devemos vêlo como agente. Hoje, se observarmos a dinâmica social da Internet, poderemos identificar, na evolução do uso das máquinas de comunicar, uma certa busca de tactilidade, reforçando ainda mais a apropriação social destas.

Como descrevemos em outro trabalho ${ }^{23}$, a tactilidade social potencializada pela microeletrônica pode ser comprovada pelas inúmeras agregações sociais. Ela é fruto de uma utilização não programada das novas tecnologias, e não um projeto de instâncias superiores. Várias ferramentas disponíveis na Internet foram criadas por usuários de forma a potencializar o lado táctil das novas tecnologias. Assim, o expoente da racionalidade científico-militar transforma-se numa busca planetária por informação e contato. Parece que a afirmação dos processos irracionais (a festa, a violência, a paixão) encontrase potencializada pelos novos recursos tecnológicos.

\section{Desvio e outsiders}

Podemos considerar os expoentes da cibercultura sob o prisma do desvio social, pela ótica do outsider ou, como propõe Howard Becker24, pela lógica da deviance (desvio). Os outsiders da cibercultura vão operar um desvio na lógica da produção e consumo das novas tecnologias contemporâneas. Embora minoritários, sua influência não é menor, sendo mesmo dominante no uso dos internautas hoje: de certa forma, todos encarnamos o espírito do hacking, ao lutarmos contra os spams, contra a invasão de privacidade, pela liberdade de expressão no ciberespaço, contra a censura, etc.

Becker lança a hipótese segundo a qual os cientistas (sociais e biomédicos) criariam uma concepção artificialista e, ao mesmo tempo, elitista do desvio social.

Esta é a maneira de enquadrálos como outsiders ou desviantes, já que estes pensam o desvio a partir das seguintes premissas: os desviantes são aqueles que não fazem parte da média, da normalidade social. Assim, os desviantes são doentes (portadores de uma patologia) que não se integram às regras gerais da normalidade social. Mas esta normalidade não é, por assim dizer, natural. Ela não é, necessariamente, patológica neste sentido, nem produto de uma enfermidade mental, mas um constructo, uma teoria.

A função de um grupo social, ou de uma organização, é definida em um contexto histórico-político e não pela natureza intrínseca do grupo. Entender 
o fenômeno da deviance, de acordo com Becker, requer aceitar que a visão funcional é inoperante, limitando a compreensão do fenômeno. A deviance é produto da sociedade, é uma falha na obediência às regras impostas. Os grupos sociais criam a deviance, fazendo suas próprias regras. Nesse sentido, a deviance não é uma qualidade do ato, mas a conseqüência da aplicação de regras comuns a grupos tidos como tal. Aí estão os outsiders.

Um ato é considerado como anticonvencional em relação a outro de acordo com a reação, tendo por parâmetro as regras gerais da moral e dos bons costumes.

No entanto, variações desta percepção se dão em função do tempo (a ocorrência e a freqüência de atos), do grau do ato (a relação entre quem comete o ato e o que é suposto de ser um ato anticonvencional), e das conseqüências sociais do ato. A deviance é um processo de interação entre pessoas (ou grupos), entre aqueles que cometem um ato e os outros que os julgam, não sendo, assim, um problema natural ou patológico, mas um conflito político-social.

Becker propõe, então, algumas categorias para os atos de desvios. Há o anticonvencional que é visto como tal, mas, em verdade, obedece a regras do grupo. Estes são os conformados anticonvencionais (por exemplo, criminosos que são vistos como tal, mas não se importam). O desviante puro é aquele que realmente está fora das regras impostas, mas que mantém, de forma conveniente, seu desvio no segredo (fumadores de maconha, por exemplo). ${ }^{25}$

Podemos aplicar a análise de Becker aos desviantes da cibercultura, aos hackers e outros outsiders da era da informação, aos cyberpunks em geral. Estes são anticonvencionais em relação aos analistas profissionais. Mais ainda, hackers ou crackers também são considerados como desviantes por seus pares. Um hacker considera um cracker desviante, mas não se enquadra enquanto tal. Alguns atos são levados em conta sem que a pessoa saiba que tal ato é proibido ou anticonvencional. Os primeiros hackers afirmam que suas ações foram realizadas na pura legalidade, que não fazem nada de doloso e que, em uma sociedade científica, tecnológica e de informação, o desejo de saber (os sistemas de computador), de liberdade (de informação) e de apropriação (da técnica) não podem ser vistos como ilegais ou anticonvencionais.

De acordo com Becker, um anticonvencional é alguém que não vive de acordo com as regras da maioria do seu grupo social. Os hackers estão nesta categoria de desviantes, estranhos aos programadores profissionais, legisladores e políticos. Eles não se vêem como criminosos, mas "como exploradores em um mundo eletrônico cujas regras não são claras". ${ }^{26}$ Os cyberpunks não compartilham posições do grupo dominante (a tecnocracia) e a imagem que lhes oferecem os mass media.

De fato, o desenvolvimento do viver em sociedade é instituído por um jogo progressivo de atos prós e contra as normas e instituições. As leis e as regras morais evoluem neste embate e, por isso, caracterizam-se como um processo aberto, sendo fruto de lutas e processos sociais complexos. No caso de hackers, suas ações são atos de diferenciação, de destaque, para uma elite de infonautas (é assim que um hacker é admitido e, sendo brilhante, adquire um status de mestre). A deviance cibernética tem um valor simbólico. De acordo com Becker, esse curso iniciático é realizado dentro de um grupo organizado, como os BBSS piratas, por exemplo. Os grupos ou tribos tendem a reforçar a deviance porque isto os une. Ao mesmo tempo, o discurso dos paladinos da era da informação mostra como esses grupos tendem, também, a racionalizar as suas práticas e a encontrar justificativas plausíveis, tentando escapar do rótulo de outsider. Becker chama isto de razão egojustificada ou ideologia. 


\section{Despesa e excesso}

Uma outra noção importante para compreendermos a cibercultura é a noção de despesa (dépense) e de excesso, particularmente com respeito aos cyberpunks. Trata-se aqui do excesso de informação, tão falado, causado pela popularização global da Internet.

A sociedade contemporânea institui-se como uma disseminação virótica de dados binários sob diversas formas: samplings musicais, vírus, pirataria, colagens digitais, etc.

G. Bataille ${ }^{27}$ vai mostrar que uma sociedade só existe se deixar um espaço reservado para despesas improdutivas, para perdas e excessos. Esta noção de excesso está na contramão do moralismo moderno, já que a acumulação capitalista e produtivista é a norma. Segundo Bataille, não há nada que nos permita definir o que é útil aos homens, já que os julgamentos, em geral, repousam sobre a produtividade social que, por sua vez, baseia-se no princípio de que todos os esforços e atividades devem ser redutíveis às necessidades materiais de produção e de conservação. Os prazeres furtivos, como a arte ou os jogos, são concessões, tendo um papel subsidiário na vida social. Como mostra Bataille,

"nesse sentido é triste dizer que a humanidade consciente continua sendo minoria: ela reconhece o direito a adquirir, a conservar ou a consumir racionalmente, mas ela exclui, em princípio, a despesa improdutiva”. ${ }^{28}$

Para Bataille, há duas formas de consumo: uma primeira, considerada útil, direcionada para a continuação da vida e das atividades de produção; e uma segunda, representada pelas atividades improdutivas, festivas, orgiásticas, excessivas. Esse autor propõe, então, que esta atividade improdutiva assuma seu caráter nobre e seja vista, como mostram sociólogos e antropólogos em estudos sobre as mais diversas sociedades primitivas, como um excesso que garante 0 verdadeiro cimento social. ${ }^{29}$

A noção de despesa como perda é ligada, aqui, à noção de sacrifício e destruição, fonte das coisas sagradas, dos jogos agonísticos e da arte em geral. Podemos ver no Potlatch essa característica do sacrifício, do dom e da destruição, já que a festa das ilhas polinésias "é o contrário do princípio de conservação: ela coloca um fim à estabilidade das fortunas tal qual existia no interior da economia totêmica, onde a posse era hereditária". ${ }^{30}$

Bataille usa o termo consumação para fazer referência ao ato de consumir a história e a vida. É no excesso que encontramos vida no planeta, já que vivemos graças às energias emanadas do Sol, aquele que dá sem nada receber, permitindo a efervescência e a multiplicação das formas de vida em toda a sua diversidade. As noções de despesa e sacrifício estão na contramão das concepções racionalistas e econômicas do século XVII, sendo que, no limiar do século XXI, a cibercultura parece crescer nesse excesso. Não é à toa que Bataille vai afirmar que:

"o ódio à despesa é a razão de ser e a justificação da burguesia: ele é, ao mesmo tempo, o princípio de sua assustadora hipocrisia". ${ }^{31}$

A cibercultura fornece vários exemplos de uma despesa excessiva, não-acumulativa e irracional de bits. Por isso a atual febre dos Portais que tentam, desesperadamente, filtrar a informação e retirar o usuário do excesso. ${ }^{32}$ Assim, dançar por horas em festas tecno, viajar por vínculos banais e efêmeros do ciberespaço, produzir vírus, penetrar sistemas de computador, trocar informação 
frívola em bate-papos e grupos temáticos, etc., refletem essa orgia de signos que preenchem nossa realidade quotidiana desse nosso tempo. Muitos intelectuais contemporâneos criticam a Internet justamente por esse caráter frívolo, de despesa e excesso improdutivo. Esse espírito conservador está na contramão das práticas sociais da cibercultura.

A despesa é, como propõe Baudrillard, aquilo que vai evitar, por introduzir pequenos desastres, o desastre total de uma racionalização da vida social, o deserto tecnológico do real. A despesa eletrônica da cibercultura é a possibilidade final de resistência à ditadura da tecnocracia, à prisão e à lógica da utilidade e da acumulação eficaz. Nesse sentido, não é a falta, nem o excesso, mas a abundância preservada e sem distribuição que representa problemas para o homem e para o planeta.

No que concerne à cibercultura, toda a ação de cyberpunks consiste em gastar o máximo de informação e colocar excessos no sistema. Contra o segredo e a acumulação da informação, os cyberpunks propõem a orgia de dados, a dança de bits pelo ciberespaço, a contaminação improdutiva de vírus, o transe, a colagem, as piratarias. $\quad \mathrm{C} \circ \mathrm{m} \mathrm{O}$ afirma Bataille, a consumação inútil "é o que me agrega (...). A consumação é a via pela qual seres separados comunicam". ${ }^{33}$

\section{Conclusão}

\section{Do Cybernanthrope ao Cyberpunk}

Segundo Henri Lefebvre ${ }^{34}$, a vida social caracteriza-se por um conjunto de instâncias diferentes, em que os poderes constituídos como a igreja, o Estado, a família e o exército sempre tentaram combater elementos residuais que causam resistência ao sistema homogeneizante. Se utilizarmos essa perspectiva de análise, podemos dizer que a cibercultura foi criada por uma espécie de resistência ao poder da tecnocracia, tratando-se mesmo de uma diferenciação em relação à utilização da tecnologia. Aqui, as ações dos cyberpunks são exemplares e vão lutar contra o que Lefebvre chama de cybernanthrope.

Usando a terminologia de Lefebvre, a grande figura da modernidade foi 0 cybernanthrope, que não é um robô, mas o humano robotizado. O cybernanthrope é, para o sociólogo francês, o tecnocrata preso a uma fascinação cega pela técnica e a sua correlata racionalidade instrumental. O robô é, como em um jogo de espelho, o trabalho do cybernanthrope, não o próprio cybernanthrope.

As tecnologias modernas reforçam a requisição energética da natureza, o controle da vida social pela administração racional a cargo de especialistas técnicos, a padronização dos costumes, a convicção em ideologias progressistas e a percepção do destino histórico. A figura que comanda esse espetáculo é o cybernanthrope. Filho da tecnologia moderna, não sendo o autômato, mas o homem automatizado que, cego, só vê o mundo pelo prisma autocentrado de sua razão onipotente. $O$ cybernanthrope é, então, o oposto da figura que poderíamos identificar como a mais emblemática da cibercultura, o cyberpunk.

O cybernanthrope quer o controle, a restrição, a estabilidade. Ele é asséptico, austero, objetivo, racional. Como explica Lefebvre, "o cybernanthrope ignora o desejo. Se ele o reconhece é para eludi-lo. O dionisíaco lhe é estranho". ${ }^{35}$

Em oposição, o cyberpunk parece mais preso a uma certa magia da informática do que à rigidez racionalista, mais dionisíaco do que apolíneo.

Um hacker, embora seja um viciado em artefatos técnicos complexos, não está muito preocupado em seguir as regras do sistema.

O cyberpunk aceita a cultura técnica do cybernanthropes no que ela tem de mais radical.

O desespero é óbvio: se não podemos 
escapar ao mundo tecnológico, devemos tornar as tecnologias ferramentas de prazer, de comunicação e de conhecimento. É esta a mensagem dos cyberpunks contra os robotizados cybernanthropes.

As novas tecnologias da cibercultura devem nos ajudar a fazer diariamente de nossa vida uma obra de arte, aqui e agora; a tecnologia deve tornar-se um instrumento fundamental de compartilhamento de experiências, de prazer estético e de busca de informação multimodal e multidirecional.

Os cybernanthropes, ao contrário, têm uma missão histórica, enquanto que os cyberpunks navegam no presente mais urgente. Podemos dizer que a estratégia do cyberpunk, através das suas diversas ações, será assim

"fundada sobre as perturbações da ordem e dos equilíbrios cybernanthrópicos. Ele deverá perpetuamente inventar, se inventar, se reinventar, queimar as pistas e os mapas do cybernanthrope, decepcioná-lo e surpreendê-lo. Para vencer, e mesmo para engajar-se na batalha, ele só pode valorizar suas imperfeições: desequilíbrios, problemas, esquecimentos, lacunas, excessos, desejos, paixão, ironia..."36

A cibercultura, com o arquétipo do hacker-cyberpunk, substitui a tecnocultura moderna com o seu especialistacybernanthrope. É a rua que vai dar formas ao novo sistema técnico da cibercultura.

Esta é a expressão do uso subversivo da tecnologia e, conseqüentemente, produto de uma atitude ativa em relação aos dispositivos técnicos.

Este fenômeno está presente em todas as ações da vida diária, marcando a falência dos cybernanthropes, superado pela despesa improdutiva de dados, pela apropriação social e pelos desvios. Este é o estilo atual da cibercultura .

Notas
1 Este artigo faz parte da pesquisa "A Cibercultura no Brasil: Aspectos da Cultura Cyberpunk", coordenada pelo autor com apoio do CNPq. As citações foram traduzidas pelo autor.

20 autor tem vários artigos publicados no Brasil e no exterior sobre a temática da cibercultura e prepara 0 livro Cibercultura: Tecnologia e Vida Social na Cultura Contemporânea, atualmente em produção na Editora Sulina, Porto Alegre, RS.

3 Para descrição ver Lemos, André, "Cultura Cyberpunk", in Textos, n. 29, Facom/UFBa, 1993.

4 Em e-mail para o newsgroup alt.cyberpunk (ragedy@cup. potal.com)

5 Em e-mail para 0 newsgroup alt.cyberpunk (bfundak@ andy.bgsu.edu)

6 Além dos livros de ficção-científica, as revistas são responsáveis pela disseminação desse imaginário tecnológico, principalmente as pioneiras Boing Boing, Hactick, 2600, Reality Hackers e depois Mondo 2000, Black Ice ou a brasileira Barata Elétrica. Uma das mais expressivas do movimento é a californiana Mondo 2000, criada em 1989 por Queen Mû e R. U. Sirius, descendente direto das antigas High Frontiers e Reality Hackers. Mondo 2000 é a bíblia dos cyberpunks e uma das primeiras a mostrar os vínculos entre a ficção-científica e a vida real.

7 Rucker, R., Sirius, R. U., Mu, Q. (Ed), Mondo 2000: A Users Guide to the New Edge, N.Y., Harpercollins Publishers, 1992., p. 13.

80 número especial Mondo 2000: A Users Guide for a New Edge é uma espécie de bíblia da cibercultura, uma enciclopédia produzida em 1992, com todos os temas caros a esse estilo tecnológico atual: cyberpunk, ficçãocientífica, realidade virtual, tecno-paganismo, smart drugs, vírus, ciberespaço, nano-tecnologias, multimídia, cibersexo, ciência pós-moderna (fractal, complexidade, caos), moda, etc.

9 Sobchack, Vivian, "New Age Mutant Ninja Hackers: Reading Mondo 2000", in Dery, M. "Flame Wars: The Discourse of Cyberculture", The South Atlantic Quarterly, 92: 4, Fall 1993, op. cit., p. 570.

10 Ruskoff, D. Um Jogo Chamado Futuro: Como a Cultura 
dos Garotos pode nos ensinar a sobreviver na era do caos, RJ, Editora Revan, 1999.

11 Sobchack, Vivian, "New Age Mutant Ninja Hackers: Reading Mondo 2000", in Dery, M. "Flame Wars: The Discourse of Cyberculture", The South Atlantic Quarterly, 92: 4, Fall 1993, op. cit.,p. 576.

12 Em Agrippa (0 livro dos Mortos), Gibson faz um livro que seria emblemático da cibercultura: virus, imediatismo, destruição de dados. 0 seu conteúdo está em cartas codificadas. Nas últimas páginas há um disquete que contém um texto de William Gibson. Assim que 0 disco é ativado, quer dizer lido por um computador, um virus causa a destruição do texto. A idéia do livro é, assim, a mesma do desaparecimento, do efêmero, do instantâneo. Assim, "the books nonappearance is linked to the disappearance of the world...". Schwenger, Peter, "Agrippa, or, The Apocalyptic Book", in Dery, M. "Flame Wars: The Discourse of Cyberculture", The South Atlantic Quarterly, 92: 4, Fall 1993, op. cit., p. 620.

13 R. U. Sirius, MU, Queen, Mondo 2000: A Users Guide to the New Edge, N.Y., Harpercollins Publishers, 1992., p. 64.

14 Sobre a cibersocialidade ver Lemos, André, "CiberSocialidade: Tecnologia e Vida Social na Cultura Contemporânea". In, Bentz, I., Rubim, A., Pinto, J. M. (org)., Práticas Discursivas na Cultura Contemporânea, Ed. Unisinos, Sao Leopoldo, 1999.

15 Hafner, K., Markoff, J., Cyberpunk: Outlaws and Hackers on the Computer Frontier, N.Y., Touchstone, 1991, p. 11.

16 Ross, A., "Hacking Away at the Counterculture", in Penley, C., Ross, A., Technoculture. Minneapolis, University of Minneapolis Press, 1992, p.132.

17 Castels, M., The Information Age: Economy, Society and Culture, Vol. 1, "The Rise of the Network Society", Massachusetts, Blackwell, 1996.

18 Ciccone, A., "Mouvement Cyberpunk", in Actuel, n¹5, Paris, Mars 1992, p. 94.

19 Perriault J., La Logique de L'Usage: Essais sur les Machines à Communiquer, Paris, Flammarion, 1989, p. 13.

20 Podemos ver o Minitel como fruto dessa apropriação social. O Minitel foi concebido como um anuário eletrônico.
A partir de várias utilizações nao previstas, como a comunicação entre usuários e o predomínio do uso erótico (no que ficou conhecido como Minitel Rose), o Minitel, de instrumento apolíneo transformou-se em ferramenta de agregação social e de práticas hedonistas. Ver Lemos, A., "The Labyrinth of Minitel", in Shields, R. (ed). Cultures of Internet, Sage, Londres, 1996.

21 A antropologia e sociologia começam a se interessar pelos usos da tecnologia no pós-guerra. Em 1965, P. Bourdieu mostra que o uso da máquina fotográfica nao só era determinado através de suas possibilidades técnicas (maquínicas) mas também pelo meio de imersão. No mesmo sentido, Dell Hymes analisa o uso do computador (numa visão antropológica) notando que o dispositivo é muito mais um "symbole de forces ultérieures" do que um instrumento racional seguindo uma lógica simples. De acordo com Perriault, a compreensao desta lógica de usos dos objetos técnicos põe o homem, e não a máquina, no centro da investigação.

22 Ver Schwach., V., "Micropsychologie des rapports homme/ machine dans la vie quotidienne", Thèse $\mathrm{dEtat,} \mathrm{Université}$ de Strasbourg, 1995.

23 Perriault J., La Logique de L'Usage: Essais sur les Machines à Communiquer, Paris, Flammarion, 1989, p. 197-198.

24 Ver Lemos, A., "Ciber-Socialidade: Tecnologia e Vida Social na Cultura Contemporânea". In, Bentz, I., Rubim, A., Pinto, J. M. (org)., Práticas Discursivas na Cultura Contemporânea, Ed. Unisinos, Sao Leopoldo, 1999.

25 Becker, Howard S., Outsiders: Studies in the Sociology of Deviance, Macmillan, 1966.

26 Becker, Howard S., Outsiders, op. cit., p.10.

27 Hafner, K., Markoff, J., Cyberpunk: Outlaws and Hackers on the Computer Frontier, N.Y., Touchstone, 1991, p.12.

28 Bataille, Georges., La Part Maudite, Paris, Editions de Minuit, 1967.

29 Idem, p. 25.

30 Idem, p. 27.

31 Idem, p. 34. 
32 Idem, p. 38.

33 Sobre excesso ver o Manifesto Morte aos Portais. Lemos, A ., "Morte aos Portais", in http://www.pilula.com.br/ morteaosportais.

34 Idem, p. 103.

35 Lefebvre, H., La Vie Quotidienne dans le Monde Moderne, Paris, Gallimard, 1968.

36 Lefebvre, H., op.cit., p. 197. 